\title{
Mom Worked: Patterns of Parenting and Attachment by Children
}

\author{
Sandy Tegariyani Putri Santoso \\ Early Childhood Department \\ Universitas Negeri Malang \\ Malang, Indonesia \\ sandy.tegariyani.fip@um.ac.id
}

\author{
Via Fahrinnia \\ Early Childhood Department \\ Universitas Negeri Malang \\ Malang, Indonesia \\ fahrinnia@gmail.com
}

\begin{abstract}
The need for self-actualization and increasing economic needs make women more and more involved to work outside the home. What if this happens if the woman had become a mother. It had an effect on the domestic sphere of a mother, especially in terms of child care. Mothers who work will involve third parties in caring for their children. It will had an impact on the pattern of care provided and how the attachment relationship between mother and child.
\end{abstract}

Keywords- working mother, parenting styles, child attachment

\section{INTRODUCTION}

The family is the smallest community unit. Each family member interacts to achieve life goals and they have their respective roles and tasks. In the conventional view, a father acts as the head of the family who provides security and fulfils all the needs of the family, while the mother acts as a manager in the family who manages all the needs in the family and nurtures her children.

The problem of working mothers is still being debated until now. The assumption of a conventional society assumes that the ideal family is a father who works in the public sector and mothers who work in the domestic sector with a variety of homework. Modern life has an impact on increasing the needs of life and the increasing need for selfactualization. Both of these are the main reasons for a mother to work outside the home.

The research conducted by Siregar shows the percentage of mothers who work at the age of 35 to 39 years as much as $12 \%$, at the age of 40 to 44 years by $72 \%$, and at the age of 45 to 49 years by $12 \%$ [1]. Looking at the data, mothers who work are in productive age assuming they have children who still need caring and nursing. While the standard working hours in Indonesia are 8 hours a day

Mothers who work in the public sector or company working hours has been determined, so that it has a limited time with their children. Working mothers' routines that leave early in the morning and go home late afternoon have an impact on the patterns of interaction and nurturing given to children. The other side effects are that mothers need replacement caregivers as long as they work outside.

The condition of mothers who work, they must combine the role of workers or employees with the care role. Limited interaction time with children will have an impact on parenting and attachment between mother and child. Mothers will also involve other parties to provide care for their children.
Parenting is the process of guiding and caring for children both physically and psychologically. The care process is characterized by the interaction between parents and children. The parenting pattern given by parents to children will determine how the attachment relationship between them.

The place where children are raised also affects children's development by determining the type of relationship between children and various family members. If the mother works outside the home and the child is cared for by relatives, or in a day care center the child's relationship with his mother will be very different from the relationship between child and mother in the family with the mother who devotes all her time and attention to the household especially during early childhood

Caring must be suited to the child's age level. Parenting is currently still dominated by mothers, the involvement of fathers in the care process is still very minimal. The care which is given to children gives a great influence on the child's development in the future.

Each stage of a child's age requires different parenting characteristics. Parenting in the early childhood will be different from parenting during the middle and late childhood [2]. The parenting pattern applied will determine the attitude of parents to children. The basic attitude of the mother to the child will influence the relationship between them.

The relationship between child and mother is very important and influences the development of emotional attachment between the two. Emotional attachment between the child and mother provides benefits to the child and also the mother. Children get a sense of security, protection and comfort from the mother, on the other hand the mother will have the opportunity to develop a healthy child's personality and be able to adapt to the social environment.

The amount of time spent by a mother to work outside the home requires mothers to look for alternative caregivers to care for their children. Some parenting alternatives commonly used by parents are leaving the child with a caregiver at home, leaving the child with the closest family at home, or using day care services.

Caregivers act as substitute parents provide more stimulation and interacting with children Supportive caregiving environments were directly predictive of peer relationship satisfaction, social emotional competence, and school readiness. From their facts we know that parenting not only given by the primary parent but also secondary care 
givers. From that statement we can say that who cares the children will influence how their behavior shaped.

Even though the mother uses substitute caregivers, the child still needs direct interaction and care from his mother. How to interact and maternal parenting patterns will have an effect on attachment between them. Here the author will describe how parenting patterns and the relationship between children and working mothers.

\section{METHOD}

This research is a single case study qualitative research. This research is specific and cannot be generalized because it uses only one research subject [3]. Determination of research subjects using purposive sampling. The researcher chose one subject, namely one family with the condition of the mother who worked in one private company and had a child who was two years old. To collect data in this study used in-depth interview techniques, as well as participating observations.

\section{RESULT AND DISCUSSION}

\section{A. Result}

\section{1) Parenting as long as mother work.}

The condition of a mother who works more than 8 hours a day requires a substitute caregiver. In this study, the mother used the services of aunt and grandmother as a surrogate caregiver while she worked. Auntie who is a housewife has free time to care for a child as long as her mother works. Most of the roles of aunts only provide care for the children they care for, such as providing food, changing diapers, and bathing children. More children are left to play alone with objects around them or play with their cousins when they are home from school. The control aunt gives to a child is very lacking. Auntie is more likely to let children play alone without ever getting involved with games played by children. Aunt still provide a response to the child, but not quickly respond when something happens to a child. Other family members involved are grandmothers who help care for children in the afternoon.

\section{2) The parenting style given by the mother to children.}

The flurry of mothers who work outside the home made while shifting the responsibility for her work until she returned home. Mother rarely invited children to communicate, mother showed affection by joking with children. Mothers are more likely to let children play alone without providing stimulation according to the child's age.

Mothers have a tendency to always obey the child's request when the child asks for a snack, but for other requests the mother tends to avoid it. Even though the mother obeys the wishes of the child, she still gives strong rules and control to the child. The mother tends to obey the commands of the child as long as the request does not make it difficult for the mother, the mother never gives physical punishment to the child but only warns when the child makes a mistake.

Mothers who work outside the home make maternal supervision of children's food intake minimal. Mother does not give enough fruit to the child, but the child still eats with vegetables and mashed rice. Mother does not forbid children when children eat foods that contain sugar such as candy, even families who care for them also provide these foods to children.

\section{3) The attachment between mother and child.}

Quantity meeting time limited children and mothers can affect the attachment relationship between them. Attachment relationship between the child and the mother can be seen from the reaction of the child saw the departure of the mother and reunited with his mother. The mother must leave the child while working or there is an urgent need that does not allow carrying the child. When the mother leaves, the child will experience separation from the mother and after separating the child will experience a reunion with the mother.

The child will whine and start crying when the child sees the mother going to work. But the child will be calm again when the mother is gone and not seen by the child. This shows the attitude of the child's protest against the departure of the mother. After the child will experience separation from the mother, the child will experience a reunion with the mother. The child's attitude can be seen from the child's reaction in welcoming the mother's arrival. The child welcomes the mother with a smile and crawls towards the mother.

\section{B. Discussion}

Mothers who work outside the home and work that mothers do, do not include work that makes it possible to care for children at work. So that care during the mother's work is given to the immediate family of the mother, namely aunt. This fact is in line with research conducted by Wheelock which reveals that parents who work, most of them will rely on family or friends to look after their children [4]. But children are more often cared for by aunts and uncles, besides that parents can rely on friends or neighbors to look after their children if emergencies or unexpected appear.

Parenting is a permissive parenting that ignores. The care provided by aunt is limited to care for children. Aunts only give a little attention and more children play alone. Aunt is also not fast in responding when children need help. This is in accordance with what was stated by Hurlock that the way to discipline is permissive, parents consider freedom (permissive) the same as letting (laissez-faire) [5]. Children fumble in situations that are too difficult for children to handle without guidance or control.

Aunt takes care of the child from morning to evening or until the mother comes home from work. Although Auntie is believed to care for children, sometimes aunts also work with grandmothers to care for children. This is because the aunt also has the responsibility of taking care of the child. This is in accordance with that expressed by Wheelock that aunts and uncles who are more often given the trust of caring for children will cooperate in with grandparents, but not only in terms of care [4].

In this case, the aunt and family should do is not just caring for children but also helping to stimulate child development. Aunts and families must interact frequently by inviting children to talk, helping children learn to walk, not allowing children to play alone by assuming that children are not having problems if left alone. In addition, families who care for them must also pay attention to food hygiene and the child's body.

Mothers who work apply permissive parenting or permissive-indulgen parenting. Caregiving applies a little 
limit or control due to lack of supervision from the mother. Mother always follows when children want something.

"I am impressed to let children do whatever they want without giving high control with the assumption that it can help stimulate child development."

This is in accordance with Baumrind's statement, mothers with permissive parenting try to show an attitude of nonpunishment, accept children with few demands, obey children's requests, and mothers allow children to do anything without high parental control [6].

Mothers who work have little time with children so that the mother's control and supervision cannot be fully done to the child. Parenting in the child's family environment also does not apply high discipline to children. When a child makes a mistake, the mother does not give an understanding of the cause and effect if the child does this. This parenting pattern is in accordance with how to discipline children according to Hurlock that in permissive discipline, it means a little discipline or not discipline [5]. Children are often not given boundaries or constraints that govern what may and cannot be done, children are permitted to make their own decisions and do their own best.

The education of mothers who only graduated from junior high schools influenced the parenting pattern a little more. In addition to formal education, the mother's minimal knowledge and experience of prior care also has an impact on care. This is in accordance with what was stated by Hurlock, parents who have parenting experience and receive training on parenting, parents will be more understanding and sensitive to children's needs [5].

In addition to the mother's knowledge and experience of care, the work of mothers as factory workers and the neighborhood where most of them are low income also affects maternal care. This is in accordance with what was stated by Hurlock concerning parents who have socioeconomic status of middle and low tend to be harder and less tolerant of children [5]. In addition, according to Santrock low maternal income can contribute to the development of eating problems in children [2].

Even though the child is one year old and can be given semi-solid food, the child sometimes eats solid foods and foods containing sugar or sweets. These foods can adversely affect future child growth. The same thing was expressed by Imsak that it is necessary to pay attention to the provision of foods containing sugar or not too much candy for children so that the teeth of the child are not perforated (caries) [8]. Another impact is mentioned by Santrock that children who consume sweetened foods and drinks and candy can cause children to be overweight [7].

In the same discussion, in the child health article, it was stated that another thing that is not less important in the child's growth and development is the cleanliness of the child and the environment. Whereas mothers and families pay little attention to children's hygiene such as not getting used to washing hands, cleaning children's items and using child diapers. The same thing was stated by Lamontagne that inadequate care in families with working mothers is usually associated with a variety of foods that are less nutritious, less use of health care, and caregivers less washing hands when touching children [9].
The parenting pattern applied will affect the quality of attachment in children because the attitude of mother's sensitivity and responsiveness in care is related to the formation of child attachments. This is consistent with what was stated by Kagan that the attitude of mothers towards children is the main determinant of open action with children [10]. In addition Bowlby also emphasized the importance of attachment in the first year of life and the importance of caregiver responsiveness [11].

If mom would go to work leaving the child, the child will be a little protest. When the mother returns from work the child welcomes the mother with a positive attitude. The attitude shown that the child has a strong or safe attachment relationship (secure attachment) with the mother. Children with strong attachments (secure attachment) consider mothers as a safe base for exploring the environment. When the mother wants to go to work or leave the child, the child will show an attitude of protest by starting to whine and if the child is not distracted to the mother, the child will start crying.

In addition to whining and crying, the child immediately crawled towards her and then asked to be carried when she was about to leave. After the mother returns from work or returns after leaving the child, the child shows a positive attitude. The child greets the mother with a smile and crawls towards the mother and asks to be carried. This is consistent with Bowlby's statement that children naturally have been positioned to form attachments to parents, especially mothers in the early years of life as a place of refuge, comfort, and place for children to ask for help [11].

\section{CONCLUSION}

Parenting patterns of working and family mothers who care for children are permissive parenting patterns. However, parenting patterns between working mothers and families are different permissive parenting. Family care is more to ignore permissive parenting, while mothers who work apply permissive parenting. The attachment between children and mothers who work is strong attachment (secure attachment), the child places the mother as a safe base to explore the environment. When the mother leaves, the child shows little protest and when the mother returns, the child will rebuild positive interactions with the mother. In addition, children who have strong attachments (secure attachment) are not hesitant in exploring the environment because children have a safe base, namely mothers.

The parenting pattern applied affects the child's attachment. The child has a strong or strong attachment relationship (secure attachment) with the mother even though the mother who works applies the same parenting pattern with the caregiving family, which is a permissive parenting pattern. But the mother is more responsive to children so that children still feel safe even if they are not near the mother.

\section{REFERENCES}

[1] M. Siregar, Bekerja, Keterlibatan Ibu. Kehidupan Buruh Perempuan Perkebunan di Desa Sukaluwei, Kecamatan Bangun Purba, Kabupaten Deli Serdang .Jurnal Harmoni Sosial, 2007, 2.1.

[2] J.W. Santrock, Essentials of life-span development. McGraw-Hill, 2014.

[3] L. J. Moleong,. "Metodologi Penelitian." Bandung: PT. Remaja Rosda Karya (1999). 
[4] J.Wheelock and Katharine Jones. "Grandparents are the next best thing': informal childcare for working parents in urban Britain." Journal of Social Policy 31.3 (2002): 441-463.

[5] E.B.Hurlock. Developmental psychology. Tata McGraw-Hill Education, 2001.

[6] D.Baumrind. "Patterns of parental authority and adolescent autonomy." New directions for child and adolescent development 2005.108 (2005): 61-69.

[7] I. Fanani. Faktor-Faktor Yang Berhubungan Dengan Pembentukan Sikap Orang Tua Dalam Meningkatkan Status Gizi Balita di
Kelurahan Merjosari Kecamatan Lowokwaru Kota Malang. Diss. University of Muhammadiyah Malang, 2011.

[8] J.F.Lamontagne., Patrice L. Engle, and Marian F. Zeitlin. "Maternal employment, child care, and nutritional status of 12-18-month-old children in Managua, Nicaragua." Social Science \& Medicine 46.3 (1998): 403-414.

[9] J. Kagan and A. M. Howard. Birth to maturity: A study in psychological development. Yale University Press, 1983. 